This paper is published in the open archive of Mid Sweden University

DIVA http://miun.diva-portal.org

with permission of the publisher

Citation for the peer-reviewed published paper:

Sjöberg J, Höglund H. Refining systems for sack paper, Part II : Plug screw and Bivis treatment under pressurised conditions and subsequent LC

refining. ; Nordic Pulp \& Paper Research Journal. 2007;22(1):61-71.

URL to article at publishers site:

http://dx.doi.org/10.3183/NPPRJ-2007-22-01-p061-071 


\title{
Plug screw and Bivis treatment under pressurized conditions and subsequent LC refining
}

\author{
Jessica C. Sjöberg and Hans Höglund, Mid Sweden University, Sundsvall, Sweden
}

KEYWORDS: Airflow resistance, Bivis equipment, Fibre length, LC refining, Plug screw, Pressurised HC refining, Sack paper, Shape factor

\begin{abstract}
SUMMARY: Unbleached kraft pulp for making sack paper is usually first refined in a high consistency process followed by low consistency refining in order to achieve desired paper properties, such as high strain at break and high tensile energy absorption at low airflow resistance. Conventional atmospheric high consistency refining is compared to treatments using two types of compressive screw equipment, Bivis equipment and the pressure expansion (PREX) plug screw feeder, commonly used in thermo mechanical pulp (TMP) plants. The plug screw pretreatments were performed under atmospheric and steam-pressurised conditions at $120^{\circ} \mathrm{C}$ and $130^{\circ} \mathrm{C}$. Treatment in the Bivis equipment was performed under different compressive and shear conditions. After the Bivis and plug screw treatments, the pulp samples were refined in a low consistency process using the Escher-Wyss refiner.

Paper properties were evaluated on freely dried sheets which were produced in order to simulate paper made under industrial sack paper drying conditions. The highest levels of the tensile energy absorption index and strain at break were achieved from curled and kinked fibres, pre-treated under the most compressive and highest shear stress conditions before low consistency refining. These results were obtained at very low airflow resistance, which is advantageous for sack paper, and with very low energy consumption during pre-treatment with the plug screw.

The pulp samples pre-treated at high consistency in a plug screw feeder under steam-pressurised conditions or in the Bivis equipment showed, after low consistency refining, increased shrinking ability compared to the pulp samples pre-treated in high consistency refining under atmospheric conditions.
\end{abstract}

\section{ADDRESS OF THE AUTHORS: Jessica C. Sjöberg (jessica.sjoberg@miun.se), Hans Höglund \\ (hans.hoglund@miun.se): Mid Sweden University, Fibre \\ Science and Communication Network, SE-851 70 Sundsvall, Sweden. \\ Corresponding author: Jessica C. Sjöberg}

Due to the increased supply of alternative packaging materials on the market, sack paper producers have come under pressure to remain competitive. This has prompted increased efforts to improve sack paper properties and lower production costs.

Paper sacks are exposed to fast filling processes. It is therefore important that sack paper be able to withstand forces experienced during filling while having low airflow resistance to prevent pressure build-up in the sack. Strain at break and the tensile energy absorption index (TEA index) are paper properties of great relevance in predicting how a sack will behave.

To improve the extensibility of sack paper, the first stage of kraft pulp processing is commonly high consi- stency (HC) refining under atmospheric conditions ( $\mathrm{HC}_{\mathrm{atm}}$ refining), a high energy consuming operation. During $\mathrm{HC}_{\mathrm{atm}}$ refining the fibres become curled and kinked due to the transfer of stresses between them (Miller 1998, Hartler 1995). $\mathrm{HC}_{\mathrm{atm}}$ refining also creates micro compressed zones in the fibre walls (Page 1966). The micro compression phenomenon has been described as a plastic deformation of the fibrillar structure of the cell wall (Hartler 1995). The transfer of stress from fibre to fibre during beating at high pulp consistencies is recognised as the causal mechanism of micro compression (Page et al. 1985). The micro compressed zones improve the extensibility of the sheet (Miller 1998, Omholt 1999). Due to fibre interactions, the shear and compressive stresses are greater in $\mathrm{HC}$ refining, so the number of micro compressed zones increases as pulp consistency is increased (Page 1966). According to previous research, pulp consistency during $\mathrm{HC}_{\mathrm{atm}}$ refining must be greater than $30 \%$ to achieve the desired pulp and sheet properties (Gullichsen and Paulapuro 1998, ScottKerr 1997). As $\mathrm{HC}_{\mathrm{atm}}$ refining creates curled and kinked fibres, which result in a low sheet density, the $\mathrm{HC}_{\mathrm{atm}}$ refining stage must be followed by a low consistency (LC) refining stage (Gullichsen and Paulapuro 1998). The objective of LC refining is to straighten fibres and improve the density in the final sheet of paper, so as to maximise the tensile strength (Gullichsen and Paulapuro 1998, Scott-Kerr 1997). Fibre deformations also imply a negative effect on paper properties such as tensile index and tensile stiffness index, those deformations are the ones that change the direction of the fibre axis, for example kinks, angular fold and twist (Mohlin et al. 1996).

There are other ways, apart from $\mathrm{HC}_{\mathrm{atm}}$ refining, of inducing curl and micro compressions in pulp fibres. Micro compressions are imparted incidentally by devices such as plug screw feeders, screw presses, and high consistency pumps and mixers. Other devices, such as the Frotapulper, deliberately impart curl and micro compressions. The Frotapulper is manufactured by AB Karlstads Mekaniska Verkstad, Karlstad, Sweden and consists of two synchronous counter-rotating intermeshing screws. The pitch of the screws diminishes from very large at the feed side to quite small at the discharge end (Pelletier et al. 1987). The beating action of a Frotapulper is a combination of shear and compression at approximately $30 \%$ consistency at a temperature of $70-90^{\circ} \mathrm{C}$. The Frotapulper produces pulp with a reduced tensile index and an increased tear index and strain at break. The changes in the appearance of the fibre include a curled form and an increased amount of micro compression in the fibre wall (Omholt 1989).

Bivis equipment - a type of extruder - was developed 
and adapted for processing non-wood fibres. The Bivis equipment is manufactured by Clextral company, Firminy/St Etienne, France. It has also been used for defibrating wood chips in TMP or chemical thermo mechanical pulp (CTMP) processes, for chemical impregnation, producing chemi-mechanical unbleached wheat straw pulp, pulp washing, and pulp bleaching (Combette 2001, Petit-Conil et al. 2001). A Bivis machine essentially consists of two identical intermeshing screws, which rotate in the same direction. The pitch of the screws can be changed along the length to define successive zones of varying compressive and shear forces.

A prior study of the $\mathrm{HC}$ refining of kraft pulp fibres under steam-pressurised $\left(\mathrm{HC}_{\text {press }}\right.$ refining) conditions in the $100-175^{\circ} \mathrm{C}$ temperature interval has found increased fibre curl and improved strain at break and TEA index at a low level of airflow resistance (Sjöberg et al. 2005). The results indicate that pre-treatment in the plug screw feeder before $\mathrm{HC}_{\text {press }}$ refining contributed significantly to increased fibre curl. It would thus be of great interest to investigate the effect of the plug screw treatment alone and also to investigate the effect of the Bivis equipment as there is a lack of studies for sack paper purpose.

The present study examined how treatment in two different types of compressive screws affected both fibre and sheet properties. In the screws, the fibres were treated with a combination of compression and shear forces. The results were then compared to the results of conventional $\mathrm{HC}_{\mathrm{atm}}$ refining under atmospheric conditions, to evaluate whether it is possible to replace the conventional $\mathrm{HC}_{\mathrm{atm}}$ refining stage with one that uses less-energy-consuming screws. Pulp samples that were treated in the screws in a first stage were also beaten in a second stage laboratory LC Escher-Wyss refiner. Fibre properties such as fibre shape and length were evaluated using an optical fibre analyser, FiberMaster (Karlsson et al. 1999) manufactured by Lorentzen \& Wettre. Physical paper properties were measured on hand-made sheets.

\section{Experimental}

\section{Pulp}

All samples used in these experiments were of commercial unbleached, undried kraft pulp obtained from Mondi Packaging Dynäs AB, in Väja, Sweden. The pulp was manufactured from a wood mix of approximately $50 \%$ spruce and $50 \%$ pine with a kappa number of approximately 43 , which corresponds to a yield of $50 \%$. The pulp was collected from a twin roll press preceding the $\mathrm{HC}$ refiner stage at different times for the two trials. The solid content was around $35 \%$ and the $\mathrm{pH}$ approximately 9.

\section{Plug screw pre-treatment}

A trial using a plug screw attached to an $\mathrm{HC}_{\text {press }}$ refiner was made at the Metso Paper R\&D Centre's pilot plant in Sundsvall, Sweden (see Fig 1). The objective was to evaluate how treatment in a commonly used plug screw affects both fibre and paper properties. Pulp was treated

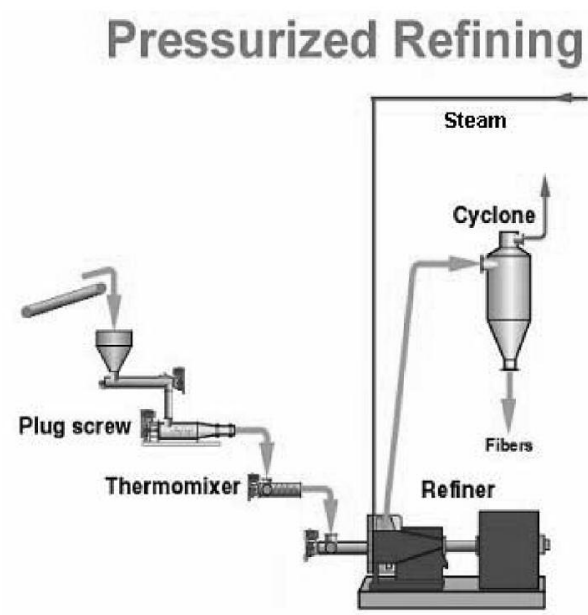

Fig 1. An illustration of the operating principle of the plug screw system and the $\mathrm{HC}_{\text {press }}$ refiner.

\section{Atmospheric Refining}

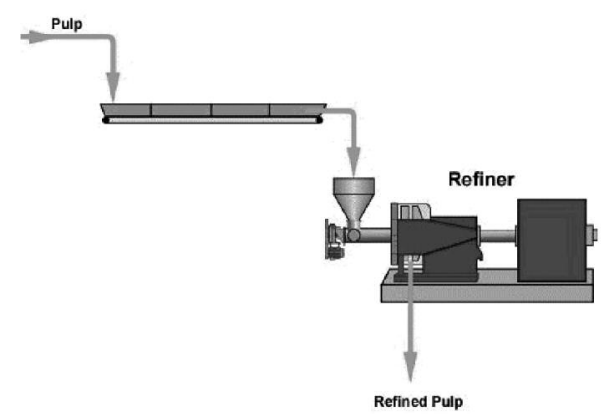

Fig 2. An illustration of the operating principle of the $\mathrm{HC}_{\text {atm }}$ refiner.

one, two, and three times in the system at $100^{\circ} \mathrm{C}, 120^{\circ} \mathrm{C}$, and $130^{\circ} \mathrm{C}$, respectively and at the corresponding steam pressures in the thermomixer. The pulp samples were then $\mathrm{HC}_{\text {press }}$ refined under steam-pressurised conditions and at corresponding temperatures. Some of the pulp samples were then selected for subsequent LC refining.

At room temperature the pulp was first fed through a plug screw with a compression ratio of 1:4 at a rate of 1 $\mathrm{kg} / \mathrm{min}$. A plug screw is a conical screw that conveys pulp to the thermomixer. In the outflow of the plug screw the pulp encountered compression stresses at the temperature current in the thermomixer. The temperature of the pulp increases along the plug screw, reaching the final temperature in the steamed and pressurised thermomixer. The dwell time in the thermomixer is 1-2 minutes. After the first treatment in the plug screw the pulp was blown through the refiner and cyclone, and immediately collected and fed into the plug screw for the second treatment, and so on. The refiner was set at the maximum plate gap to avoid mechanically treating the fibres. The refiner was equipped with 20 -inch segments, type 5811S, and the refiner speed was $1500 \mathrm{rpm}$, manufactured by Metso Paper.

Pulp was also $\mathrm{HC}_{\text {atm }}$ refined under conventional atmospheric conditions (see Fig 2), as is pulp treated in commercial sack paper mills; the objective was to use this pulp as a reference. Pulp was fed into the refiner at a 
rate of $1 \mathrm{~kg} / \mathrm{min}$. The refiner was equipped with 20 -inch segments, type 5811S, and the refiner speed was $1500 \mathrm{rpm}$.

\section{Bivis pre-treatment}

The Bivis equipment, manufactured by Clextral company, at the pilot mill (Firminy/St Etienne, France) was used for the trial. A schematic illustration of a Bivis machine appears in Fig 3. The machine consists of two identical intermeshing screws, which rotate in the same direction. The pitch of the screws changes along their length so as to define successive zones of varying compressive forces. The initial pitch is wide to move material downstream; in the next zone, the pitch is reversed. There are several reversal zones along the length of the screws. In these zones the material flow is obstructed and forced to pass through narrow slots; considerable amounts of material accumulate, creating high compression combined with shear forces. The size and number of slots have a significant effect on the quality of the pulp produced (Petit-Conil et al. 2001).

Pulp was fed to the twin-screw extruder at a rate of 1 $\mathrm{kg} / \mathrm{min}$. The process parameters used in the trial are shown in Table 1 in the Appendix. Two different screw profiles are referred to in Table 1: profile 1 gave a gentler treatment while profile 2 gave the toughest kneading of the fibres. Reference pulp after $\mathrm{HC}_{\mathrm{atm}}$ refining was collected at Mondi Packaging Dynäs AB, in Väja, Sweden for comparison with the results of the Bivis trial.

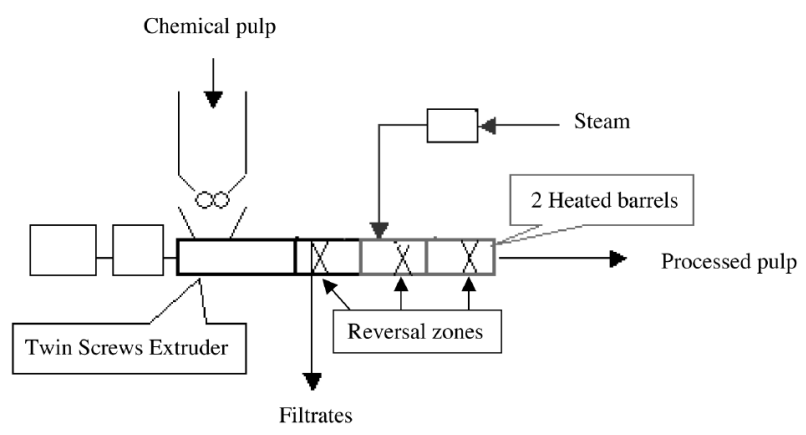

Fig 3. An illustration of the operating principle of the Bivis equipment.

\section{Low consistency refining}

For LC refining, an Escher-Wyss conical refiner at the SCA Technology Centre in Sundsvall, Sweden was used to simulate the LC refining process used by commercial sack paper producers. The pulp was refined according to a standard method used at the SCA Technology Centre. Pulp consistency during refining was approximately $2 \%$ and the edge load was $1.26 \mathrm{Ws} / \mathrm{m}$. The pulp suspension was circulated until the target refining energy level was obtained.

\section{Fibre analysis}

The length-weighted average fibre length and shape factor were analysed in non-dried pulp samples using the FibreMaster optical fibre analyser (Karlsson et al. 1999). The pulp was defibrated in cold water according to the SCAN-C 18:65 method before analysis. The results from each sample were based on data from approximately 10000 fibres. Fibres are defined as particles with a length/width ratio greater than 4 . The definition of the shape factor is the projected fibre length divided by the true fibre length, i.e. a completely straight fibre has a shape factor of $100 \%$. The water retention value was measured using the SCAN-C 62:00 method.

\section{Sheet preparation}

Sheets were made using the ISO-M 5:67 method, and the physical properties of the paper were tested according to SCAN-P 67:93. Freely dried sheets were made by hand like ordinary ISO-M 5:67 sheets until the point of stacking. The stack was composed by placing a pressing plate at the bottom, followed by two dry blotters, a couching blotter, a laboratory sheet, and three dry blotters. This sequence was repeated for every laboratory sheet, until finally a second pressing plate was placed on top of the stack. The sheets were pressed at $490 \mathrm{kPa}$ for four minutes; all the blotters were then removed and the sheets were dried between Teflon wires on a drying drum at 60 $\pm 5^{\circ} \mathrm{C}$ for approximately two hours.

\section{Result and Discussion}

\section{Plug screw pre-treatment and $\mathrm{HC}_{\mathrm{atm}}$ or $\mathrm{HC}_{\text {press }}$ refining and subsequent LC refining}

\section{Evaluation of fibre properties}

Plug screw pre-treatment

The length-weighted fibre length changed only slightly during treatment in the plug screw (see Table 2 in the Appendix). Drainage resistance (Schopper-Riegler number) decreased slightly, which confirms that no fibre cutting occurred during treatment in the plug screw. The length-weighted shape factor decreased with the number of treatments in the plug screw (see Fig 4). Temperature had a significant effect on fibre curl. The most curled fibres were produced by pulp treated three times in the plug screw at $120-130^{\circ} \mathrm{C}$. This could be because higher temperature and pressure produce more compression and shear stresses during treatment in the plug screw.

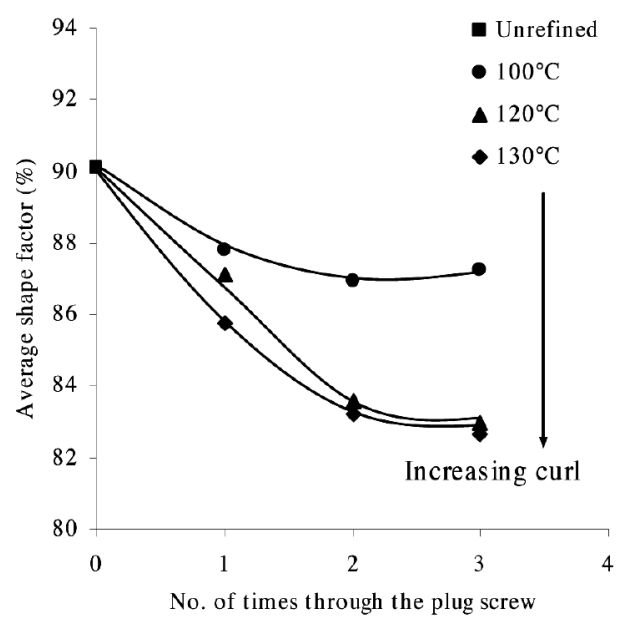

Fig 4. Average shape factor versus treatment one to three times in a plug screw at different temperatures 


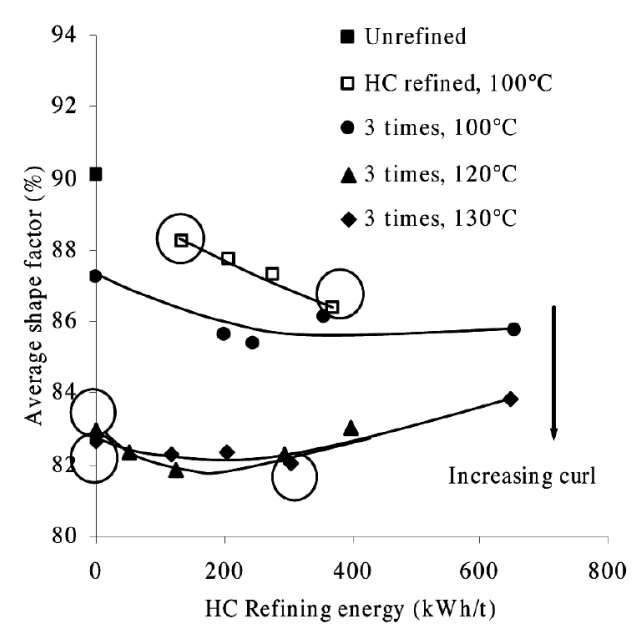

Fig 5. Average shape factor versus $\mathrm{HC}_{\text {atm }}$ and $\mathrm{HC}_{\text {press }}$ refining energy

\section{HC refining}

After the pulp samples had been treated three times in the plug screw at different temperatures, the pulp samples were then $\mathrm{HC}_{\text {atm }}$ or $\mathrm{HC}_{\text {press }}$ refined at the same temperatures as those at which the pulp samples were treated in the plug screw. Pulp samples were also $\mathrm{HC}_{\text {atm }}$ refined in a pilot refiner at $100^{\circ} \mathrm{C}$ at different energy consumption levels, as a reference simulating standard mill practice.

Length-weighted fibre length decreased slightly with increased $\mathrm{HC}_{\text {atm }}$ refining energy (see Table 3 in the Appendix). Fibres treated three times in the plug screw actually increased in length in some cases. This could be an effect of straightening out the curled fibres, as FiberMaster only measures the fibres in two dimensions and the fibres curl in three.

The length-weighted average shape factor increased slightly for pulps treated under pressurised conditions (see Fig 5). For pulp samples treated under atmospheric conditions, the average shape factor decreased during $\mathrm{HC}_{\mathrm{atm}}$ refining, i.e. the amount of curl increased, but it required considerable $\mathrm{HC}_{\text {atm }}$ refining energy to achieve a certain curl level. The most curled fibres were obtained from pulp treated three times in the plug screw at $120^{\circ} \mathrm{C}$ and $130^{\circ} \mathrm{C}$, meaning that the more compressive stresses the fibres were exposed to, the more curled the fibres. These curled fibres were achieved with very low energy consumption during plug screw treatment, 10-20 $\mathrm{kWh} / \mathrm{ton}$. This could be an effect of more efficient kneading due to the higher compression that occurs during treatment in the plug screw under greater than atmospheric pressures. During treatment in the $\mathrm{HC}_{\text {atm }}$ or $\mathrm{HC}_{\text {press }}$ refiner, fibres that were pre-treated in the plug screw were only slightly affected in terms of fibre curl.

\section{LC refining}

The pulp samples indicated by circles in Fig 5 were LC refined. These samples were chosen in order to evaluate the effect of quite large differences in energy consumption and also the effect of treatment in the plug screw. Length-weighted fibre length decreased with increased energy consumption during LC refining (see Table 3 in the Appendix). The length of fibres treated three times in the plug screw and fibres treated with traditional $\mathrm{HC}_{\text {atm }}$ refining decreased in a similar way.

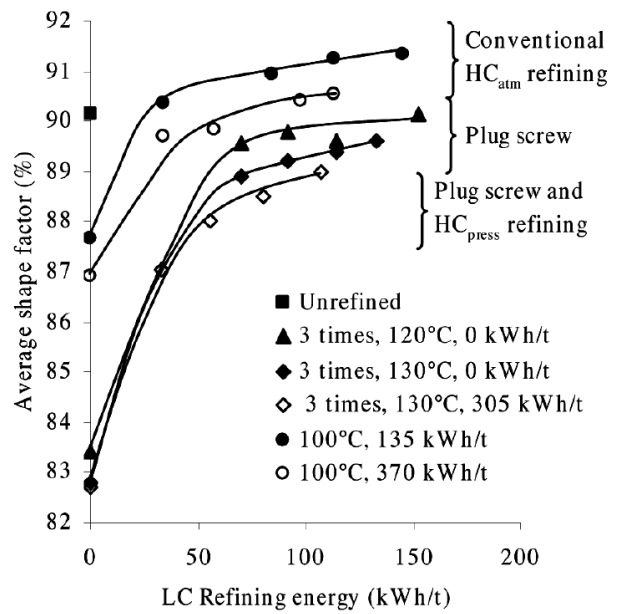

Fig 6. The change in average shape factor during subsequent $L C$ refining

The length-weighted shape factor increased with increased energy consumption during LC refining (see Fig 6). The most curled fibres were obtained in pulp treated three times in the plug screw at $130^{\circ} \mathrm{C}$ and then $\mathrm{HC}_{\text {press }}$ refined at $305 \mathrm{kWh} / \mathrm{t}$ during $\mathrm{LC}$ refining. On the whole, the pulp samples treated three times in the plug screw with very low energy consumption, $10-20 \mathrm{kWh} / \mathrm{t}$, are the most curled fibres after LC refining compared to the pulp samples that were $\mathrm{HC}_{\text {atm }}$ refined.

\section{Evaluation of paper properties}

The ability to stretch is largely determined by sheet shrinkage during drying. Where a high strain at break is needed, e.g. in sack paper, attempts should be made to increase the paper shrinkage (Htun and de Ruvo 1981, Page 1971, Wahlström 1999). The tensile index increases and strain at break decreases with increasing strain during drying, meaning the more a sheet shrinks, the higher strain at break is achieved in the paper (Wahlström 1999). To investigate this behaviour, freely dried handmade sheets were made. The measured properties of the freely dried hand-made sheets after LC refining are shown in Figs 7-10. The physical paper properties were evaluated as a function of airflow resistance. Airflow resistance increased with increasing $\mathrm{LC}$ refining. Airflow resistance is a very important paper property for sack paper. It is thus very advantageous to achieve the desired paper properties at low airflow resistance levels.

The measured physical paper properties of ISO-M 5:67 hand-made sheets after LC refining are shown in Table 3 in the Appendix. These results show trends similar to those of the freely dried sheets.

The density, strain at break, tensile index, and TEAindex increased with increased LC refining energy. Denser sheets were obtained from pulp that had been $\mathrm{HC}_{\text {atm }}$ or $\mathrm{HC}_{\text {press }}$ refined at the highest refining energy. Pulp samples treated three times in the plug screw achieved much better strain at break than did pulp samples that were $\mathrm{HC}_{\text {atm }}$ refined. This can probably be explained by a difference in fibre curl and the amount of micro compression in the fibre walls, as an increased amount of micro compression results in greater sheet extensibility (Miller 1998). 


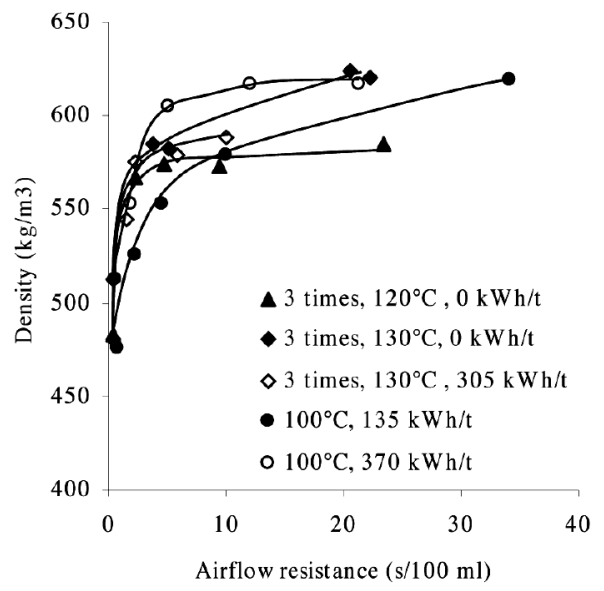

Fig 7. The relationship between density and airflow resistance after plug screw treatment, $\mathrm{HC}_{\text {atm }}$ or $\mathrm{HC}_{\text {reses }}$ refining and subsequent $\mathrm{LC}$ refining of freely dried handmade sheets

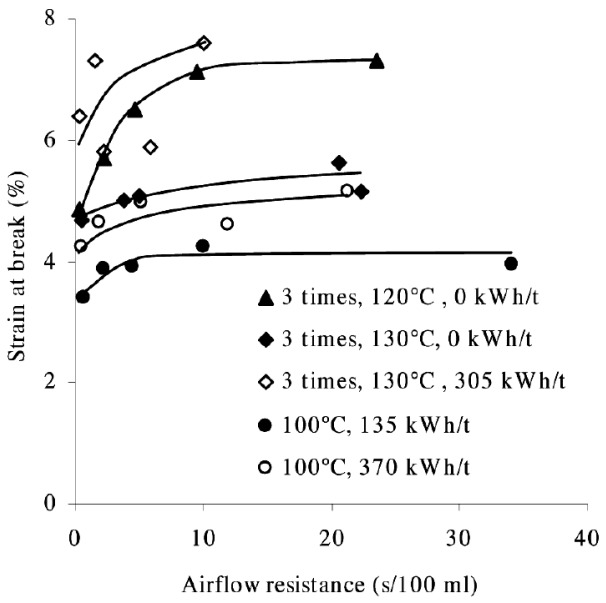

Fig 8. The relationship between strain at break and airflow resistance after plug screw treatment, $\mathrm{HC}_{\text {atm }}$ or $\mathrm{HC}_{\text {press }}$ refining and subsequent $\mathrm{LC}$ refining of freely dried hand-made sheets

Sheets made of pulp $\mathrm{HC}_{\text {atm }}$ refined achieved a higher tensile index. Pulp treated three times in the plug screw at $130^{\circ} \mathrm{C}$ and thereafter $\mathrm{HC}_{\text {press }}$ refined at $305 \mathrm{kWh} / \mathrm{t}$ and pulp treated three times in the plug screw at $120^{\circ} \mathrm{C}$ achieved the best TEA-index level. The greatest increase in strain at break and TEA-index occurred at low airflow resistance values.

\section{Bivis pre-treatment followed by LC refining}

The pulp for the Bivis trial was collected from a twin roll press installed before the $\mathrm{HC}_{\text {atm }}$ refiner stage in the mill, the same position as for the plug screw trial. The pulp was collected on a later occasion, so the origin pulps for the two trials are not the same. Two screw profiles were used: profile 1 gave a gentler treatment and profile 2 gave the toughest kneading of the fibres. In Figs 11-15 the effect of Bivis treatment can be seen at $0 \mathrm{kWh} / \mathrm{t}$ on the $\mathrm{x}$-axis.

\section{Evaluation of fibre properties}

The length of the reference fibres decreased slightly more than that of the unbeaten and Bivis-treated pulp fibres at the same energy consumption level during LC refining (see Table 5 in the Appendix). Length-weighted shape factor increased with increased energy consumption during LC refining (see Fig 11). The greatest fibre

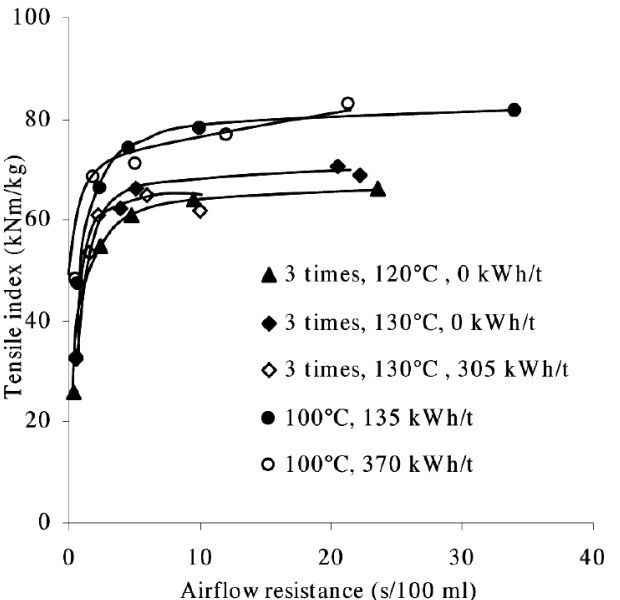

Fig 9. The relationship between tensile index and airflow resistance after plug screw treatment, $\mathrm{HC}_{\text {atm }}$ or $\mathrm{HC}_{\text {press }}$ refining and subsequent $\mathrm{LC}$ refining of freely dried hand-made sheets

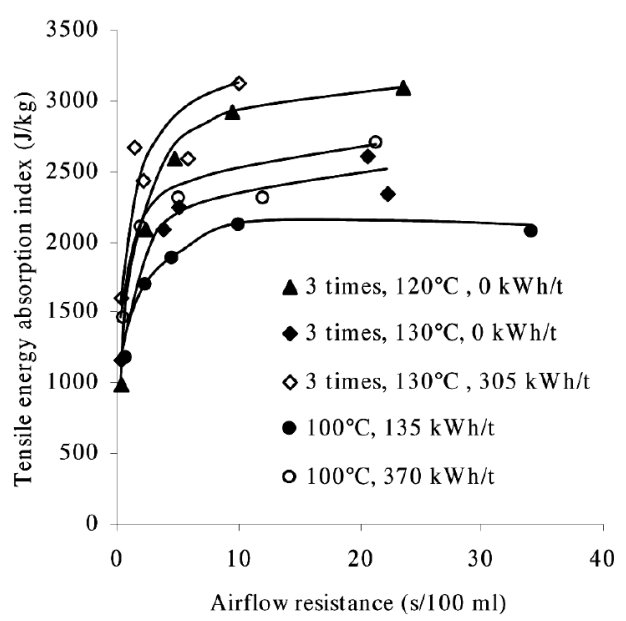

Fig 10. The relationship between TEA-index and airflow resistance after resistance after plug screw treatment, $\mathrm{HC}_{\text {atm }}$ or $\mathrm{HC}_{\text {press }}$ refining and subsequent refining of freely dried hand-made sheets

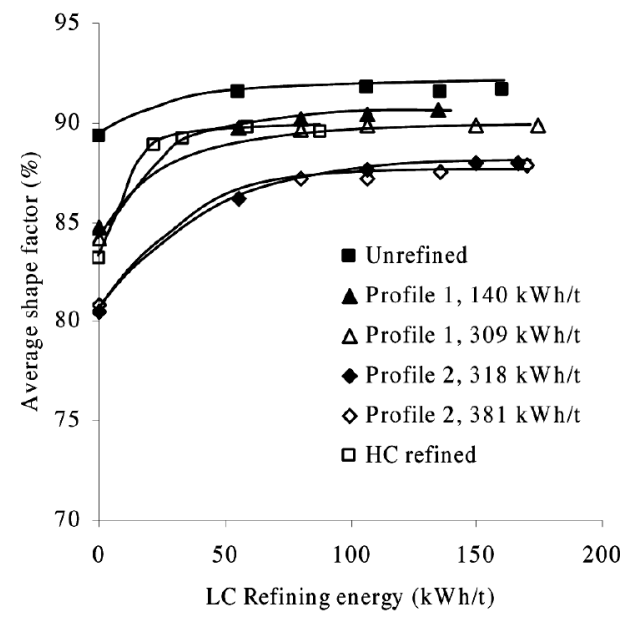

Fig 11. The change in average shape factor during Bivis treatment with different screw profiles and levels of energy consumption and subsequent LC refining

curl was observed in pulp subject to Bivis treatment with screw profile 2 .

\section{Evaluation of paper properties}

The measured properties of the ISO-M 5:67 hand-made sheets, made from LC refined pulp, are shown in Table 5 in the Appendix. To clarify the results, the unrefined 


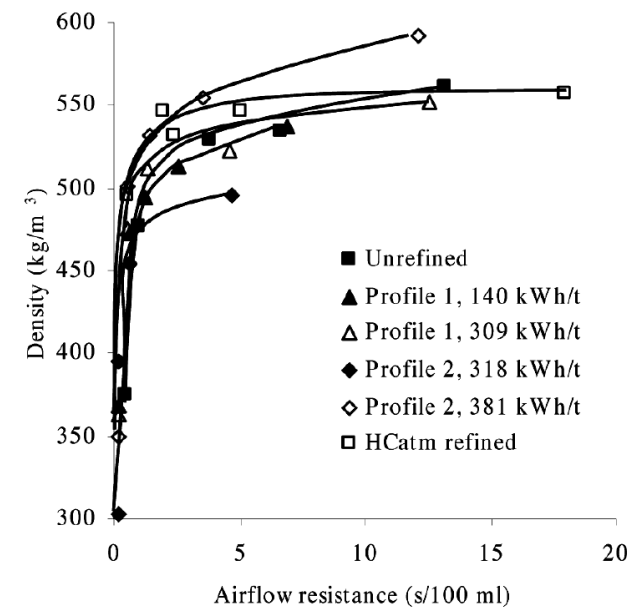

Fig 12. The relationship between density and airflow resistance after treatment in Bivis or $\mathrm{HC}_{\text {atm }}$ refining and subsequent $\mathrm{LC}$ refining of freely dried hand-made sheets

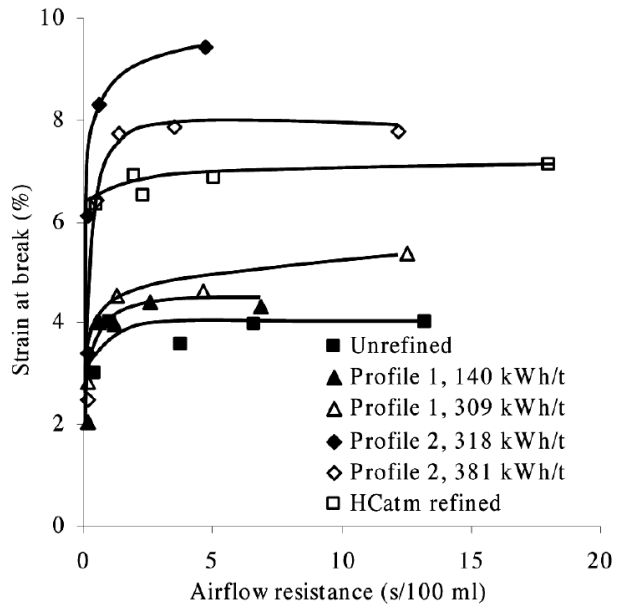

Fig 13. The relationship between strain at break and airflow resistance after treatment in Bivis or $\mathrm{HC}_{\text {atm }}$ refining and subsequent $\mathrm{LC}$ refining of freely dried handmade sheets

pulp sample was only LC refined (not $\mathrm{HC}$ refined), and the HC refined pulp sample was obtained from Mondi Packaging Dynäs $A B$, in Väja, Sweden. These results show trends similar to those of the freely dried sheets. As mentioned earlier, the ability to stretch is largely determined by sheet shrinkage during drying, thus where a high strain at break is needed, for example, in sack paper, attempts should be made to increase the paper shrinkage. For this reason, only the results for the freely dried sheets are commented on here

Figs 12-15 present the physical paper properties. Beating degree is described by the change of airflow resistance, as airflow resistance increased with increasing LC refining.

The density increased with increasing LC refining (see Fig 12). The densest sheets were obtained from pulp treated with profile 2 screws in Bivis equipment at the highest energy level; the next-densest sheets were produced from the mill reference pulp sample. Strain at break increased with increased LC refining (see Fig 13), the greatest increase occurring at low airflow resistance values and with fibres treated with profile 2 screws in the Bivis equipment. The tensile index increased with

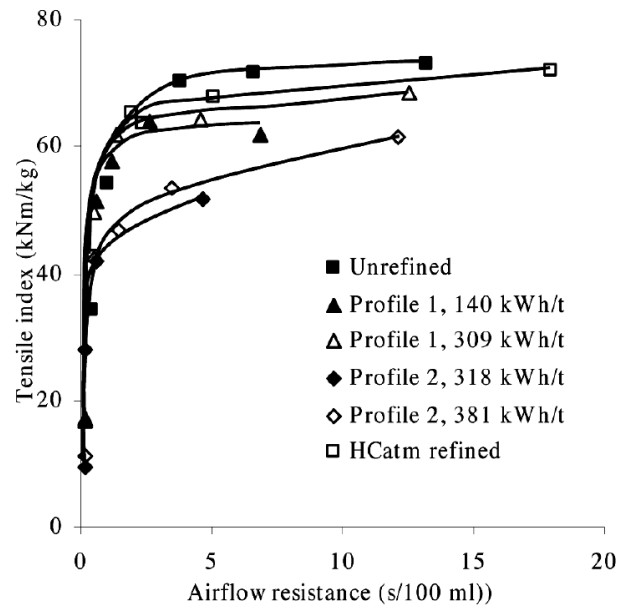

Fig 14. The relationship between tensile index and airflow resistance after treatment in Bivis or $\mathrm{HC}_{\text {atm }}$ refining and subsequent $\mathrm{LC}$ refining of freely dried handmade sheets

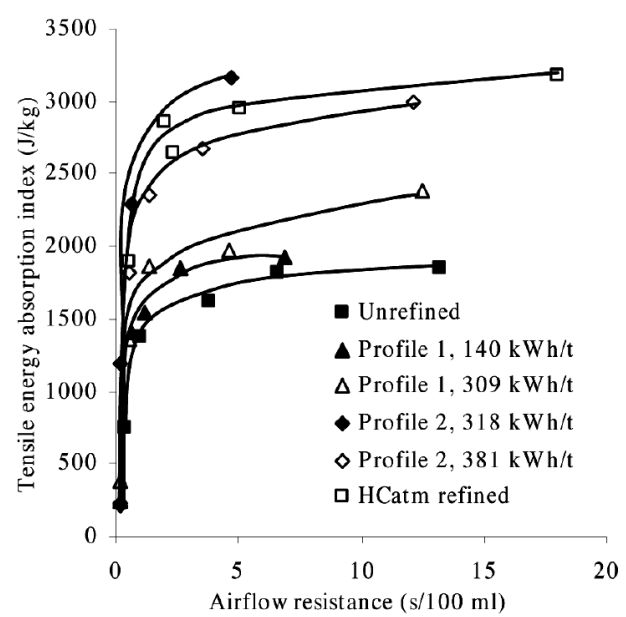

Fig 15. The relationship between TEA-index and airflow resistance after treatment in Bivis or $\mathrm{HC}_{\text {atm }}$ refining and subsequent $\mathrm{LC}$ refining of freely dried hand-made sheets

increased LC refining (see Fig 14). TEA-index increased with increased LC refining for all pulp samples (see Fig 15), the best TEA-index being obtained from fibres treated with profile 2 screws in the Bivis equipment.

Increased fibre-to-fibre interaction in the sheet structure increases the sheet strength, stretch, and elastic modulus. On the other hand, the introduction of curl and micro compressions increases stretch, but lowers the dry sheet tensile strength and elastic modulus (Seth et al. 1983). When the increased strain at break due to HC refining starts to diminish, the strength of the sheet may be reduced to such an extent, due to increased fibre curl, reduced swelling, or a reduced bonded area, that the stretch potential of the fibres before rupture can no longer be exploited (Omholt 1999). Therefore, increased strain at break is followed by reduced tensile index, and vice versa. This agrees with the results from both the plug screw trial and the Bivis trial. Treatment under pressurised conditions, using high temperature in the plug screw and the screw profile producing the toughest kneading in the Bivis, seems to have a significant influence on pulp samples. Paper properties such as strain at break and TEA-index increase with increased 
compression during treatment in both the plug screw and the Bivis equipment. The temperature was also varied in the two trials. The plug screw trial showed that higher temperatures result in higher levels of fibre curl, strain at break, and TEA-index, but decreased tensile index levels. These results are in accordance with those of an earlier study of $\mathrm{HC}_{\text {press }}$ refining (Sjöberg et al. 2005). The number of times that pulp samples are treated in the plug screw has the same effect as temperature does. However, it is difficult to draw any conclusions from the influence of different temperatures in the Bivis trial (see Table 1 in the Appendix). Though the temperature of the barrels was varied from $47^{\circ} \mathrm{C}$ to $174^{\circ} \mathrm{C}$ using electric heaters located in the cover of the intermeshing screws, the temperature of the pulp, measured in the outlet, did not vary significantly. The significant effect of the Bivis treatment is therefore probably due to the screw profile, as the profile giving the toughest kneading treatment resulted in higher levels of fibre curl, strain at break, and TEA-index but decreased tensile index after LC refining.

\section{Evaluation of sheet shrinkage}

The shrinkage of the pulp samples from the plug screw and Bivis trials was evaluated. The strain at break was evaluated as a function of shrinkage to determine how the two qualities correlate (see Fig 16). The diagram shows that strain at break, especially for pulp samples exposed to the most compressive treatment, is dependent on the degree of sheet shrinkage during drying. The results show that the more the sheet shrinks, the higher the level of strain at break achieved. Pulp samples treated three times in the plug screw achieved better strain at break than did the atmospherically refined pulps, and these samples also displayed greater shrinkage. The results from the Bivis trial similarly showed that the pulp samples exposed to greater compression and shear stresses during treatment shrank more and achieved higher strain at break.

\section{Conclusion}

Unbleached kraft pulp treated under compressive and shear conditions in a steam-pressurised PREX screw has more curled fibres than does pulp refined in an atmospheric $\mathrm{HC}$ refiner $\left(\mathrm{HC}_{\mathrm{atm}}\right.$ refiner). The degree of fibre curl increases with the number of times the fibres have been treated in the plug screw. Fibre curl also increases when the screw profile producing the most intense kneading is used in the Bivis equipment.

Evaluation of freely dried hand-made sheets showed that if pre-treatment in an $\mathrm{HC}_{\text {atm }}$ refining system is replaced by pre-treatment in a plug screw or in Bivis equipment, the produced pulp achieves a higher strain at break and TEA-index after LC refining. On the other hand, the tensile index is somewhat higher for the pulp pre-treated in a $\mathrm{HC}_{\text {atm }}$ refiner. This result was achieved at a very low airflow resistance level.

The development of strain at break was better in pulp samples treated under the highest possible level of compression. The results from the plug screw trial showed that the greater the number of times pulp samples were treated in the plug screw at very low energy consumption levels, the higher the strain at break after LC refining. When the screw profile that gives the most intense kneading treatment of the fibres, due to compressive forces, is used in the Bivis treatment, the pulp samples achieve higher strain at break after LC refining.

A system with some kind of plug screw pre-treatment, preferably under steam-pressurised conditions, makes it possible to produce pulp for kraft sack paper with high strain at break and TEA-index levels and low airflow resistance with reduced energy consumption. The disadvantage of this technique is the reduced tensile index.

\section{Future work}

This study shows that it may be possible to replace the $\mathrm{HC}_{\text {atm }}$ refining stage with pulp treatment in a plug screw at high temperature and still achieve the same effects. To investigate the role of lignin in the effects found in the present study, bleached kraft pulp will be $\mathrm{HC}_{\text {press }}$ refined and examined. It is also important to understand the fundamentals of what happens in the fibre walls under $\mathrm{HC}_{\text {press }}$ refining. This has been studied using nuclear magnetic resonance (NMR) methods. New methods using chemical additives to improve the bond strength of paper made from fibres treated in pressurised

Fig 16. The relationship between strain at break and shrinkage after $\mathrm{HC}_{\text {atm }}$ or $\mathrm{HC}_{\text {press }}$ refining and/or screw treatment and subsequent $\mathrm{LC}$ refining of freely dried hand-made sheets 
systems so as to achieve high strain at break, have been studied: future research should delve deeper into these methods.

\section{Acknowledgements}

The authors wish to thank Mondi Packaging Dynäs AB for their financial support, for supplying us with kraft pulp, and for sharing their valuable knowledge of sack paper production. We would also like to thank the staff of SCA Graphic Research and of the Metso R\&D Centre in Sweden for their assistance. Prof. Myat Htun of Mid Sweden University is thanked for his valuable comments. Finally, the authors acknowledge Proper English AB for linguistic revision.

\section{Literature}

Combette, P. (2001): Introduction of a Non-Conventional Pulping Process for the Pulping of Non-Wood Fibres and Crop Residues, Conference proceedings, Amsterdam, Netherlands, 17-18 0ct., 11 pp Leatherhead, UK, Pira International. Gullichsen, J. and Paulapuro, H. (1998): FAPET - Papermaking Part 1, Stock Preparation and Wet End, Published in cooperation with the Finnish Paper Engineers' Association and TAPPI.

Hartler, N. (1995): Aspects on curled and microcompressed fibers, Nord. Pulp Paper Res. J. vol 10 no. 1, 4-7.

Htun, M. and de Ruvo, A. (1981): The influence of drying strategies on the relationship between drying shrinkage and strain to failure of paper, The Role of Fundamental Research in Papermaking Symposium, vol. 2, 385-398, September, Cambridge, UK.

Karlsson, H., Fransson, P-I. and Mohlin, U-B. (1999): STFI FIBERMASTER, SPCl, 6th International Conference on New Available Technologies, June 3, Stockholm, Sweden, 1-4 June, 367-374.

Miller, P.R. (1989): Fibre and Sheet Properties resulting from Refining Stock Consistency Variation, Appitavol. 42, no.2 Mar., 125-130.

Mohlin, U-B, Dahlbom, J. and Hornatowska, J. (1996): Fiber deformation and sheet strength, Tappi J. vol. 79(No. 6), June, 105-111.
Omholt, I. (1989): Frotapulper treated fibre, PFI Nytt, no. 4, Nov., 3-5.

Omholt, I. (1999): The Effects of Curl and Microcompressions on the Combination of Sheet Properties, TAPPI International Paper Physics Conference San Diego, CA, USA, 26-30 Sept., 499-515.

Page, D.H. (1971): The structure and properties of paper Part II. Shrinkage, dimensional stability and stretch. "This paper is reprinted from the magazine TREND, No. 18, Spring, by permission of the Pulp and Paper Research Institute of Canada", 13-19

Page, D.H., Seth, R.S., Jordan, B.D. and Barbe, M.C. (1985): Curl, Crimps, Kinks and Microcompressions in Pulp Fibres -their Origin, Measurement and Significance, Transaction of the Eighth Fundamental Research Symposium, Oxford(1): 183

Page, D.H. (1966): The Axial Compression of Fibres - A Newly Discovered Beating Action, Pulp Paper Mag. Can. 67(1), Jan., 2-12.

Pelletier, L.J., Seth, R.S., Barbe, M.C. and Page, D.H. (1987): The Effect of High-Consistency Mechanical Treatment on the Properties of Sulphite Pulps, J. Pulp Paper Sci. vol. 13 No. 4 July, 121-125.

Petit-Conil, M., Brochier, B., Labalette, F. and Combette P. (2001): Potential of wheat straw to produce chemimechanical pulps suited to corrugating papers manufacture, TAPPI Pulping Conference, Seattle, WA, USA, 4-7 Nov., $11 \mathrm{pp}$.

Scott-Kerr, C. (1997): Manufacture of Multiwall Sack Papers, 82nd Annual meeting, Technical Section, Pulp Paper Can. vol. 98, no. 5, May, 45-48.

Seth, R.S., Page, D.H., Barbe, M.C. and Jordan, B.D. (1983): The mechanism of the strength and extensibility of wet webs, International Paper Physics Conference, Tappi proceedings, 73-81.

Sjöberg, J.C. and Höglund, H. (2005): Refining systems for sack paper pulp: Part I HC refining under pressurised conditions and subsequent LC refining, Nord. Pulp Paper Res. J. vol 20 no. 3, 320-328.

Wahlström, T. (1999): Influence of Shrinkage and Stretch During Drying on Paper Properties, Licentiate Thesis, Department of Pulp and Paper Chemistry and Technology, Royal Institute of Technology, Stockholm, Sweden.

Manuscript received July 15, 2005 Accepted November 11, 2006

\section{Appendix}

Table 1. Process parameters and results of the Bivis trial.

\begin{tabular}{|c|c|c|c|c|c|c|c|c|c|c|}
\hline $\begin{array}{l}\text { Screws } \\
\text { profile } \\
\text { nb }\end{array}$ & $\begin{array}{l}\text { Steam } \\
(\mathrm{kg} / \mathrm{h})\end{array}$ & $\begin{array}{l}\text { Pulp } \\
\text { output } \\
\text { (kg/h) }\end{array}$ & $\begin{array}{c}\text { Pulp } \\
\text { dryness output } \\
(\%)\end{array}$ & $\begin{array}{c}\text { Pulp } \\
\text { temp. output } \\
\left({ }^{\circ} \mathrm{C}\right)\end{array}$ & $\begin{array}{l}\text { Pulp } \\
\text { pH }\end{array}$ & $\begin{array}{l}\mathrm{T} 1 \\
\left({ }^{\circ} \mathrm{C}\right)\end{array}$ & $\begin{array}{l}\mathrm{T} 2 \\
\left({ }^{\circ} \mathrm{C}\right)\end{array}$ & $\begin{array}{l}\mathrm{T} 3 \\
\left({ }^{\circ} \mathrm{C}\right)\end{array}$ & $\begin{array}{l}\mathrm{T} 4 \\
\left({ }^{\circ} \mathrm{C}\right)\end{array}$ & $\begin{array}{c}\text { Energy } \\
\text { consumed } \\
(\mathrm{kWh} / \mathrm{t})\end{array}$ \\
\hline 1 & 50 & 142 & 40.9 & 86 & 9 & 82 & 119 & 131 & 130 & 140 \\
\hline 1 & 0 & 135 & 44 & 76 & 9 & 47 & 65 & 173 & 174 & 309 \\
\hline 2 & 25 & 125 & 47.3 & 75 & 9 & 73 & 124 & 129 & 106 & 318 \\
\hline 2 & 0 & 133 & 43.1 & 80 & 9 & 59 & 72 & 153 & 126 & 381 \\
\hline
\end{tabular}

Table 2. Process parameters of the plug screw trial.

\begin{tabular}{|c|c|c|}
\hline $\begin{array}{l}\text { No. of times through } \\
\text { the plug screw }\end{array}$ & $\begin{array}{l}\text { Average fibre length } \\
(\mathrm{mm})\end{array}$ & SR \\
\hline \multicolumn{3}{|l|}{ Untreated pulp } \\
\hline 0 & 2,27 & 14,5 \\
\hline \multicolumn{3}{|c|}{ Pulp treated in the plug screw at $100^{\circ} \mathrm{C}$} \\
\hline 1 & 2,16 & 12 \\
\hline 2 & 2,17 & 11,5 \\
\hline 3 & 2,07 & 12,5 \\
\hline
\end{tabular}

Table 2. Process parameters of the plug screw trial.

\begin{tabular}{|c|c|c|}
\hline $\begin{array}{l}\text { No. of times through } \\
\text { the plug screw }\end{array}$ & $\begin{array}{l}\text { Average fibre length } \\
(\mathrm{mm})\end{array}$ & SR \\
\hline \multicolumn{3}{|c|}{ Pulp treated in the plug screw at $120^{\circ} \mathrm{C}$} \\
\hline 1 & 2,21 & 14,5 \\
\hline 2 & 2,11 & 13 \\
\hline 3 & 2,11 & 13,5 \\
\hline \multicolumn{3}{|c|}{ Pulp treated in the plug screw at $130^{\circ} \mathrm{C}$} \\
\hline 1 & 2,20 & 13 \\
\hline 2 & 2,13 & 14 \\
\hline 3 & 2,11 & 14 \\
\hline
\end{tabular}


Table 3. Pulp and hand-made ISO sheet data for plug screw and HC refined pulp and subsequent LC refining.

\begin{tabular}{|c|c|c|c|c|c|c|c|c|}
\hline $\begin{array}{l}\text { Energy } \\
\text { consumed in } \\
\text { EscherWyss } \\
(\mathrm{kWh} / \mathrm{t})\end{array}$ & SR & $\begin{array}{l}\text { Density } \\
\left(\mathrm{kg} / \mathrm{m}^{3}\right)\end{array}$ & $\begin{array}{l}\text { Tensile index } \\
\text { (kNm/kg) }\end{array}$ & $\begin{array}{l}\text { Tensile energy } \\
\text { abs. index } \\
(\mathrm{J} / \mathrm{kg})\end{array}$ & $\begin{array}{c}\text { Strain at } \\
\text { break } \\
(\%)\end{array}$ & $\begin{array}{l}\text { Tensile } \\
\text { stiffness } \\
\text { index } \\
(\mathrm{MNm} / \mathrm{kg})\end{array}$ & $\begin{array}{l}\text { Airflow } \\
\text { resistance } \\
(\mathrm{s} / 100 \mathrm{ml})\end{array}$ & $\begin{array}{c}\text { Average } \\
\text { fibre length } \\
\text { (mm) }\end{array}$ \\
\hline \multicolumn{9}{|c|}{ Unrefined pulp } \\
\hline & 14,5 & 588 & 40,7 & 716 & 2,5 & 5,2 & 1,0 & 2,27 \\
\hline \multicolumn{9}{|c|}{ Pulp treated 3 times in the plug screw at $120^{\circ} \mathrm{C}$ and subsequent LC refining } \\
\hline 0 & 13,5 & 610 & 36,9 & 1070 & 3,8 & 4,0 & 0,7 & 2,23 \\
\hline 71 & 17,5 & 675 & 70,9 & 1770 & 3,7 & 6,2 & 3,1 & 2,08 \\
\hline 92 & 21 & 691 & 73,6 & 1800 & 3,6 & 6,4 & 5,9 & 2,03 \\
\hline 115 & 24,5 & 719 & 81,6 & 2020 & 3,7 & 6,9 & 12,1 & 2,03 \\
\hline 153 & 32,5 & 738 & 85,8 & 2030 & 3,6 & 7,3 & 42,9 & 1,93 \\
\hline \multicolumn{9}{|c|}{ Pulp treated 3 times in the plug screw at $130^{\circ} \mathrm{C}$ and subsequent $\mathrm{LC}$ refining } \\
\hline 0 & 14,5 & 651 & 41,9 & 1340 & 4,2 & 4,6 & 0,9 & 2,26 \\
\hline 71 & 21,0 & 708 & 74,1 & 1980 & 3,9 & 6,8 & 6,0 & 2,09 \\
\hline 92 & 24,0 & 722 & 76,1 & 1990 & 3,8 & 6,8 & 9,4 & 2,08 \\
\hline 115 & 29,5 & 727 & 82,9 & 2150 & 3,8 & 7,2 & 28,1 & 2,03 \\
\hline 1335 & 35,5 & 746 & 83,3 & 2130 & 3,8 & 7,1 & 41,4 & 2,00 \\
\hline \multicolumn{9}{|c|}{ Pulp treated 3 times in the plug screw $\mathrm{HC}_{\text {press }}$ refined with $305 \mathrm{kWh} / \mathrm{t}$ at $130^{\circ} \mathrm{C}$ and subsequent $\mathrm{LC}$ refining } \\
\hline 0 & 14,5 & 662 & 45,3 & 1650 & 4,9 & 4,6 & 0,9 & 2,25 \\
\hline 33 & 18,0 & 700 & 66,9 & 2120 & 4,6 & 5,9 & 2,7 & 2,11 \\
\hline 56 & 21,0 & 701 & 68,7 & 2050 & 4,3 & 6,1 & 4,1 & 2,07 \\
\hline 80 & 26,0 & 711 & 75,8 & 2270 & 4,4 & 6,5 & 9,6 & 2,03 \\
\hline 107 & 31,0 & 729 & 79,7 & 2310 & 4,3 & 6,8 & 18,1 & 1,98 \\
\hline \multicolumn{9}{|c|}{ Pulp treated with conventional $\mathrm{HC}_{\text {atm }}$ refining at $135 \mathrm{kWh} / \mathrm{t}, 100^{\circ} \mathrm{C}$ and subsequent $\mathrm{LC}$ refining } \\
\hline 0 & 15,0 & 650 & 57,0 & 1470 & 3,6 & 5,9 & 1,7 & 2,39 \\
\hline 34 & 17,5 & 667 & 75,3 & 1590 & 3,1 & 7,1 & 4,1 & 2,26 \\
\hline 84 & 21,0 & 709 & 82,7 & 1680 & 3,1 & 7,6 & 9,9 & 2,15 \\
\hline 114 & 24,5 & 726 & 89,2 & 1930 & 3,3 & 7,9 & 14,5 & 2,09 \\
\hline 146 & 33,0 & 751 & 92,2 & 1910 & 3,2 & 8,3 & 43,3 & 2,02 \\
\hline \multicolumn{9}{|c|}{ Pulp treated with conventional $\mathrm{HC}_{\text {atm }}$ refining at $370 \mathrm{kWh} / \mathrm{t}, 100^{\circ} \mathrm{C}$ and subsequent $\mathrm{LC}$ refining } \\
\hline 0 & 16,5 & 683 & 58,6 & 1580 & 3,8 & 6,0 & 1,2 & 2,30 \\
\hline 34 & 19,5 & 707 & 78,7 & 2050 & 3,8 & 7,1 & 4,1 & 2,18 \\
\hline 58 & 22,0 & 720 & 81,6 & 1940 & 3,5 & 7,3 & 6,7 & 2,18 \\
\hline 98 & 28,0 & 737 & 90,4 & 2010 & 3,3 & 8,0 & 17,8 & 2,09 \\
\hline 114 & 32,0 & 744 & 93,7 & 2150 & 3,4 & 8,2 & 28,8 & 2,07 \\
\hline
\end{tabular}

Table 4. Pulp and hand-made freely dried sheet data for plug screw and HC refined pulp and subsequent LC refining.

\begin{tabular}{|c|c|c|c|c|c|c|c|c|}
\hline $\begin{array}{l}\text { Energy } \\
\text { consumed in } \\
\text { EscherWyss } \\
(\mathrm{kWh} / \mathrm{t})\end{array}$ & SR & $\begin{array}{l}\text { Density } \\
\left(\mathrm{kg} / \mathrm{m}^{3}\right)\end{array}$ & $\begin{array}{l}\text { Tensile index } \\
\text { (kNm/kg) }\end{array}$ & $\begin{array}{l}\text { Tensile energy } \\
\text { abs. index } \\
(\mathrm{J} / \mathrm{kg})\end{array}$ & $\begin{array}{c}\begin{array}{c}\text { Strain at } \\
\text { break }\end{array} \\
\text { (\%) }\end{array}$ & $\begin{array}{c}\text { Tensile } \\
\text { stiffness } \\
\text { index } \\
(\mathrm{MNm} / \mathrm{kg})\end{array}$ & $\begin{array}{l}\text { Airflow } \\
\text { resistance } \\
(\mathrm{s} / 100 \mathrm{ml})\end{array}$ & $\begin{array}{c}\text { Average } \\
\text { fibre length } \\
(\mathrm{mm})\end{array}$ \\
\hline $\begin{array}{l}\text { Unrefined pulp } \\
0\end{array}$ & 14,5 & 408 & 24,7 & 571 & 3,1 & 2,8 & 0,4 & 2,27 \\
\hline \multicolumn{9}{|c|}{ Pulp treated 3 times in the plug screw at $120^{\circ} \mathrm{C}$ and subsequent LC refining } \\
\hline 0 & 13,5 & 483 & 26,0 & 980 & 4,9 & 2,7 & 0,4 & 2,23 \\
\hline 71 & 17,5 & 567 & 55,0 & 2080 & 5,7 & 4,3 & 2,3 & 2,08 \\
\hline 92 & 21 & 575 & 61,1 & 2580 & 6,5 & 4,3 & 4,7 & 2,03 \\
\hline 115 & 24,5 & 573 & 63,9 & 2920 & 7,1 & 4,3 & 9,5 & 2,03 \\
\hline 153 & 32,5 & 585 & 66,1 & 3090 & 7,3 & 4,4 & 23,5 & 1,93 \\
\hline \multicolumn{9}{|c|}{ Pulp treated 3 times in the plug screw at $130^{\circ} \mathrm{C}$ and subsequent $\mathrm{LC}$ refining } \\
\hline 0 & 14,5 & 513 & 32,5 & 1160 & 4,7 & 3,3 & 0,5 & 2,26 \\
\hline 71 & 21,0 & 585 & 62,1 & 2090 & 5,0 & 5,0 & 3,9 & 2,09 \\
\hline 92 & 24,0 & 582 & 66,0 & 2240 & 5,1 & 5,3 & 5,1 & 2,08 \\
\hline 115 & 29,5 & 620 & 68,9 & 2340 & 5,2 & 5,3 & 22,3 & 2,03 \\
\hline 133 & 35,5 & 623 & 70,5 & 2610 & 5,6 & 5,1 & 20,6 & 2,00 \\
\hline
\end{tabular}




\begin{tabular}{|c|c|c|c|c|c|c|c|c|}
\hline $\begin{array}{l}\text { Energy } \\
\text { consumed in } \\
\text { EscherWyss } \\
(\mathrm{kWh} / \mathrm{t})\end{array}$ & SR & $\begin{array}{l}\text { Density } \\
\left(\mathrm{kg} / \mathrm{m}^{3}\right)\end{array}$ & Tensile index & $\begin{array}{l}\text { Tensile energy } \\
\text { abs. index } \\
(\mathrm{J} / \mathrm{kg})\end{array}$ & $\begin{array}{c}\begin{array}{c}\text { Strain at } \\
\text { break }\end{array} \\
(\%)\end{array}$ & $\begin{array}{c}\text { Tensile } \\
\text { stiffness } \\
\text { index } \\
(\mathrm{MNm} / \mathrm{kg})\end{array}$ & $\begin{array}{c}\text { Airflow } \\
\text { resistance } \\
\text { (s/100 ml) }\end{array}$ & $\begin{array}{c}\text { Average } \\
\text { fibre length } \\
\text { (mm) }\end{array}$ \\
\hline \multicolumn{9}{|c|}{ Pulp treated 3 times in the plug screw and $\mathrm{HC}_{\text {press }}$ refined with $305 \mathrm{kWh} / \mathrm{t}$ at $130^{\circ} \mathrm{C}$ and subsequent $\mathrm{LC}$ refining } \\
\hline 0 & 14,5 & 481 & 32,8 & 1600 & 6,4 & 3,0 & 0,4 & 2,25 \\
\hline 33 & 18,0 & 545 & 53,5 & 2670 & 7,3 & 4,1 & 1,5 & 2,11 \\
\hline 56 & 21,0 & 576 & 60,7 & 2430 & 5,8 & 4,8 & 2,3 & 2,07 \\
\hline 80 & 26,0 & 579 & 65,0 & 2580 & 5,9 & 5,0 & 5,9 & 2,03 \\
\hline 107 & 31,0 & 589 & 62,0 & 3120 & 7,6 & 4,2 & 10,0 & 1,98 \\
\hline \multicolumn{9}{|c|}{ Pulp treated with conventional $\mathrm{HC}_{\text {atm }}$ refining with $135 \mathrm{kWh} / \mathrm{t}$ at $100^{\circ} \mathrm{C}$ and subsequent $\mathrm{LC}$ refining } \\
\hline 0 & 15,0 & 476 & 47,6 & 1170 & 3,4 & 4,9 & 0,7 & 2,39 \\
\hline 34 & 17,5 & 525 & 66,2 & 1700 & 3,9 & 5,7 & 2,3 & 2,26 \\
\hline 84 & 21,0 & 552 & 74,2 & 1890 & 3,9 & 6,1 & 4,5 & 2,15 \\
\hline 114 & 24,5 & 579 & 77,9 & 2110 & 4,3 & 6,1 & 10,0 & 2,09 \\
\hline 146 & 33,0 & 619 & 81,4 & 2070 & 4,0 & 6,6 & 34,1 & 2,02 \\
\hline \multicolumn{9}{|c|}{ Pulp treated with conventional $\mathrm{HC}_{\text {atm }}$ refining with $370 \mathrm{kWh} / \mathrm{t}$ at $100^{\circ} \mathrm{C}$ and subsequent $\mathrm{LC}$ refining } \\
\hline 0 & 16,5 & 513 & 48,2 & 1470 & 4,2 & 4,6 & 0,6 & 2,30 \\
\hline 34 & 19,5 & 553 & 68,3 & 2110 & 4,6 & 5,6 & 1,9 & 2,18 \\
\hline 58 & 22,0 & 605 & 71,1 & 2310 & 5,0 & 5,5 & 5,1 & 2,18 \\
\hline 98 & 28,0 & 617 & 76,7 & 2310 & 4,6 & 6,1 & 12,0 & 2,09 \\
\hline 114 & 32,0 & 616 & 82,8 & 2710 & 5,1 & 5,9 & 21,4 & 2,07 \\
\hline
\end{tabular}

Table 5. Pulp and hand-made ISO sheet data for Bivis treated pulp and subsequent LC refining.

\begin{tabular}{|c|c|c|c|c|c|c|c|c|}
\hline $\begin{array}{l}\text { Energy } \\
\text { consumed in } \\
\text { EscherWyss } \\
(\mathrm{kWh} / \mathrm{t})\end{array}$ & SR & $\begin{array}{l}\text { Density } \\
\left(\mathrm{kg} / \mathrm{m}^{3}\right)\end{array}$ & $\begin{array}{l}\text { Tensile index } \\
\text { (kNm/kg) }\end{array}$ & $\begin{array}{l}\text { Tensile energy } \\
\text { abs. index } \\
(\mathrm{J} / \mathrm{kg})\end{array}$ & $\begin{array}{c}\begin{array}{c}\text { Strain at } \\
\text { break }\end{array} \\
(\%)\end{array}$ & $\begin{array}{c}\text { Tensile } \\
\text { stiffness } \\
\text { index } \\
(\mathrm{MNm} / \mathrm{kg})\end{array}$ & $\begin{array}{c}\text { Airflow } \\
\text { resistance } \\
(\mathrm{s} / 100 \mathrm{ml})\end{array}$ & $\begin{array}{c}\text { Average } \\
\text { fibre length } \\
\text { (mm) }\end{array}$ \\
\hline \multicolumn{9}{|c|}{ Pulp LC refined only } \\
\hline 0 & 14,0 & 590 & 51,8 & 1100 & 3,0 & 5,4 & 1,2 & 2,61 \\
\hline 56 & 17,5 & 663 & 77,6 & 1390 & 2,8 & 7,3 & 3,3 & 2,38 \\
\hline 106 & 21,0 & 698 & 89,6 & 1690 & 2,9 & 7,8 & 11,6 & 2,24 \\
\hline 136 & 26,0 & 709 & 91,3 & 1630 & 2,8 & 8,2 & 19,4 & 2,21 \\
\hline 160 & 30,0 & 720 & 94,0 & 1760 & 2,9 & 8,2 & 35,0 & 2,13 \\
\hline
\end{tabular}

\begin{tabular}{|c|c|c|c|c|c|c|c|c|}
\hline \multicolumn{9}{|c|}{ Pulp treated using screw profile 1 at $140 \mathrm{kWh} / \mathrm{t}$ and subsequent $\mathrm{LC}$ refining } \\
\hline 0 & 13,5 & 566 & 27,9 & 570 & 2,8 & 3,4 & 0,4 & 2,29 \\
\hline 56 & 17,5 & 643 & 66,1 & 1550 & 3,4 & 6,3 & 1,6 & 2,22 \\
\hline 80 & 19,5 & 671 & 71,3 & 1580 & 3,3 & 6,8 & 3,4 & 2,16 \\
\hline 106 & 23,5 & 678 & 77,4 & 1730 & 3,3 & 7,2 & 7,5 & 2,13 \\
\hline 134 & 29,5 & 705 & 84,4 & 1890 & 3,6 & 7,6 & 25,0 & 2,03 \\
\hline \multicolumn{9}{|c|}{ Pulp treated using screw profile 1 at $309 \mathrm{kWh} / \mathrm{t}$ and subsequent $\mathrm{LC}$ refining } \\
\hline 0 & 13,0 & 584 & 25,0 & 600 & 3,2 & 3,1 & 0,3 & 2,22 \\
\hline 80 & 17,0 & 658 & 67,1 & 1690 & 3,7 & 6,3 & 1,6 & 2,19 \\
\hline 106 & 19,5 & 671 & 70,7 & 1650 & 3,4 & 6,5 & 3,4 & 2,16 \\
\hline 150 & 26,5 & 696 & 78,4 & 1900 & 3,6 & 6,7 & 11,9 & 2,10 \\
\hline 175 & 31,5 & 706 & 80,4 & 1910 & 3,5 & 7,3 & 29,6 & 2,06 \\
\hline \multicolumn{9}{|c|}{ Pulp treated using screw profile 2 at $318 \mathrm{kWh} / \mathrm{t}$ and subsequent $\mathrm{LC}$ refining } \\
\hline 0 & 12,0 & 447 & 16,9 & 330 & 2,5 & 2,4 & 0,2 & 2,15 \\
\hline 56 & 15,0 & 594 & 42,2 & 1130 & 3,7 & 4,5 & 0,4 & 2,25 \\
\hline 106 & 19,0 & 634 & 54,9 & 1600 & 4,1 & 5,3 & 1,3 & 2,20 \\
\hline 150 & 24,5 & 666 & 65,0 & 1970 & 4,3 & 5,9 & 4,9 & 2,17 \\
\hline 166 & 30,0 & 672 & 68,5 & 2130 & 4,5 & 6,1 & 9,1 & 2,15 \\
\hline \multicolumn{9}{|c|}{ Pulp treated using screw profile 2 at $381 \mathrm{kWh} / \mathrm{t}$ and subsequent $\mathrm{LC}$ refining } \\
\hline 0 & 12,5 & 525 & 19,9 & 400 & 2,5 & 2,7 & 0,2 & 2,17 \\
\hline 80 & 18,5 & 643 & 59,7 & 1580 & 3,7 & 5,6 & 1,5 & 2,32 \\
\hline 106 & 19,5 & 669 & 65,8 & 1780 & 3,9 & 6,0 & 2,9 & 2,35 \\
\hline 136 & 25,0 & 685 & 70,8 & 1890 & 3,8 & 6,4 & 7,1 & 2,32 \\
\hline 170 & 34,0 & 709 & 76,7 & 2050 & 3,9 & 6,8 & 27,2 & 2,27 \\
\hline \multicolumn{9}{|c|}{ Pulp $\mathrm{HC}_{\text {atm }}$ refined in Dynäs pulp mill at approximately $350 \mathrm{kWh} / \mathrm{t}$ and subsequent $\mathrm{LC}$ refining } \\
\hline 0 & 16,0 & 678 & 56,9 & 1660 & 4,1 & 5,5 & 0,8 & 2,31 \\
\hline 22 & 19,5 & 700 & 78,3 & 2030 & 3,8 & 6,7 & 2,8 & 2,13 \\
\hline 33 & 21,0 & 723 & 84,2 & 2240 & 3,9 & 7,0 & 5,0 & 2,10 \\
\hline 59 & 26,0 & 731 & 87,2 & 2170 & 3,7 & 7,3 & 12,0 & 2,03 \\
\hline 88 & 31,5 & 737 & 95,2 & 2380 & 3,8 & 7,8 & 34,1 & 2,02 \\
\hline
\end{tabular}


Table 6. Pulp and hand-made freely dried sheet data for Bivis treated pulp and subsequent LC refining.

\begin{tabular}{|c|c|c|c|c|c|c|c|c|}
\hline $\begin{array}{l}\text { Energy } \\
\text { consumed in } \\
\text { EscherWyss } \\
(\mathrm{kWh} / \mathrm{t})\end{array}$ & SR & $\begin{array}{l}\text { Density } \\
\left(\mathrm{kg} / \mathrm{m}^{3}\right)\end{array}$ & $\begin{array}{l}\text { Tensile index } \\
(\mathrm{kNm} / \mathrm{kg})\end{array}$ & $\begin{array}{l}\text { Tensile energy } \\
\text { abs. index } \\
(\mathrm{J} / \mathrm{kg})\end{array}$ & $\begin{array}{c}\text { Strain at } \\
\text { break } \\
(\%)\end{array}$ & $\begin{array}{c}\text { Tensile } \\
\text { stiffness } \\
\text { index } \\
(\mathrm{MNm} / \mathrm{kg})\end{array}$ & $\begin{array}{c}\text { Airflow } \\
\text { resistance } \\
\text { (s/100 ml) }\end{array}$ & $\begin{array}{c}\begin{array}{c}\text { Average } \\
\text { fibre length } \\
(\mathrm{mm})\end{array}\end{array}$ \\
\hline \multicolumn{9}{|c|}{ Pulp LC refined only } \\
\hline 0 & 14,0 & 374 & 34,1 & 750 & 3,0 & 3,9 & 0,1 & 2,61 \\
\hline 56 & 17,5 & 477 & 54,1 & 1380 & 4,0 & 4,1 & 1,0 & 2,38 \\
\hline 106 & 21,0 & 529 & 70,3 & 1630 & 3,6 & 5,7 & 3,8 & 2,24 \\
\hline 136 & 26,0 & 534 & 71,7 & 1810 & 4,0 & 5,7 & 6,6 & 2,21 \\
\hline 160 & 30,0 & 562 & 73,1 & 1850 & 4,0 & 5,7 & 13,2 & 2,13 \\
\hline \multicolumn{9}{|c|}{ Pulp treated using screw profile 1 at $140 \mathrm{kWh} / \mathrm{t}$ and subsequent $\mathrm{LC}$ refining } \\
\hline 0 & 13,5 & 369 & 16,7 & 240 & 2,0 & 2,0 & 0,2 & 2,29 \\
\hline 56 & 17,5 & 473 & 51,2 & 1400 & 4,0 & 4,5 & 0,6 & 2,22 \\
\hline 80 & 19,5 & 495 & 57,6 & 1540 & 4,0 & 5,0 & 1,2 & 2,16 \\
\hline 106 & 23,5 & 513 & 63,9 & 1860 & 4,4 & 5,2 & 2,6 & 2,13 \\
\hline 134 & 29,5 & 537 & 61,7 & 1920 & 4,3 & 4,7 & 6,9 & 2,03 \\
\hline \multicolumn{9}{|c|}{ Pulp treated using screw profile 1 at $309 \mathrm{kWh} / \mathrm{t}$ and subsequent $\mathrm{LC}$ refining } \\
\hline 0 & 13,0 & 363 & 17,1 & 380 & 2,8 & 2,2 & 0,2 & 2,22 \\
\hline 80 & 17,0 & 476 & 49,7 & 1360 & 4,0 & 4,5 & 0,6 & 2,19 \\
\hline 106 & 19,5 & 512 & 61,9 & 1860 & 4,5 & 5,0 & 1,3 & 2,16 \\
\hline 150 & 26,5 & 522 & 64,4 & 1970 & 4,6 & 5,1 & 4,6 & 2,10 \\
\hline 175 & 31,5 & 552 & 68,6 & 2390 & 5,4 & 5,1 & 12,5 & 2,06 \\
\hline \multicolumn{9}{|c|}{ Pulp treated using screw profile 2 at $318 \mathrm{kWh} / \mathrm{t}$ and subsequent $\mathrm{LC}$ refining } \\
\hline 0 & 12,0 & 303 & 9,3 & 230 & 3,4 & 1,0 & 0,2 & 2,15 \\
\hline 56 & 15,0 & 396 & 28,0 & 1200 & 6,1 & 2,0 & 0,2 & 2,25 \\
\hline 106 & 19,0 & 454 & 41,8 & 2290 & 8,3 & 2,5 & 0,6 & 2,20 \\
\hline 166 & 30,0 & 495 & 51,8 & 3160 & 9,5 & 2,8 & 4,7 & 2,15 \\
\hline \multicolumn{9}{|c|}{ Pulp treated using screw profile 2 at $381 \mathrm{kWh} / \mathrm{t}$ and subsequent $\mathrm{LC}$ refining } \\
\hline 0 & 12,5 & 349 & 11,3 & 220 & 2,5 & 1,7 & 0,2 & 2,17 \\
\hline 80 & 18,5 & 501 & 42,3 & 1820 & 6,4 & 3,0 & 0,5 & 2,32 \\
\hline 106 & 19,5 & 531 & 47,0 & 2350 & 7,7 & 2,8 & 1,4 & 2,35 \\
\hline 136 & 25,0 & 555 & 53,6 & 2670 & 7,9 & 3,0 & 3,5 & 2,32 \\
\hline 170 & 34,0 & 593 & 61,5 & 3000 & 7,8 & 3,3 & 12,2 & 2,27 \\
\hline \multicolumn{9}{|c|}{ Pulp $\mathrm{HC}_{\text {tm }}$ refined in Dynäs pulp mill at approximately $350 \mathrm{kWh} / \mathrm{t}$ and subsequent $\mathrm{LC}$ refining } \\
\hline 0 & 16,0 & 495 & 42,7 & 1900 & 6,3 & 3,5 & 0,5 & 2,31 \\
\hline 22 & 19,5 & 546 & 65,5 & 2860 & 6,9 & 4,2 & 2,0 & 2,13 \\
\hline 33 & 21,0 & 532 & 63,5 & 2640 & 6,5 & 4,2 & 2,4 & 2,10 \\
\hline 59 & 26,0 & 546 & 67,9 & 2940 & 6,8 & 4,3 & 5,1 & 2,03 \\
\hline 88 & 31,5 & 558 & 71,9 & 3180 & 7,1 & 4,3 & 18,0 & 2,02 \\
\hline
\end{tabular}

